\title{
CULPA E RESPONSABILIDADE EM HERÁCLITO SEGUNDO A LEITURA HEIDEGGERIANA
}

Mario Fleig*

SINTESB - O artigo trata, dentro da perspectiva de Heidegger, da culpa/dívida e da responsabilldade em sua fundamentaçāo ontológica, tanto na perspectiva de uma ontologia fundamental de Ser $\theta$ tempo, quanto na interpretaçẫo nâo metafisica do Lögos de Heráclito, Como resultado, apontase para o fundamento da lógica/linguagem e da ética tio Lógos originảio de Hetáclito, encaminhando a necagsidade de uma nove concepçăo da essência do homem.

PALAVRAS-CHAVE - Etica, culpa, Iesponsabilidade, linguagem, lógica.
ABSTRACT - Within Heidegger's perspective, the paper dea's with guit/debt and with responsability in their ontological foundation, both from the point of view of a fundamental ontology in Boing and Time and from the nonmetaphysical interpretation of the Heraclitus' Logos. As a result, the foundation of logid langugere and of ethics in the Lógos originating in Heraclitus is pointed out, thus paving the way for the necessity of a new conception of the essence of manking.

KEY WORDS - ethics, guilt, responsahility, language, logic.

A temática da culpa a da responsabilidade na obra de Heidegger remete inexoravelmente à questão da definiçâo do ser do homem. Recusando e criticando a definiçäo corrente assumida na tradição ocidental, na esteira da formulação aristotélica - zoon logon echon - Heidegger se empenha em resgatar o que ficou esquecido nesse traço específico do ser do homem: o lógos. Isso nos habilita a perseguir as relaçőes entre o fenômeno da consciência moral (Gewissen) e a desmontagern da lógica ocidental em busca do lógos angináno em Herácilto. Está claro que Heidegger se lança na elaboração de uma lógica que caminha na contramão das lógicas cientificas: trata-șe de um lógica do lógos.

* Protessor da Universidade do Vale do Rio dos Sinos - UNISivos e membro da Associaçăo Psicanalitica de Porto Alegre.

\begin{tabular}{|l|l|l|l|l|l|}
\hline VERTTAS & Porto Alegre & v. 43 & $n^{2} 1$ & Março 1998 & p. $55-80$
\end{tabular}




\section{1- A culpa/divida originária em Ser e tempo e a linguagem}

Abordar a questảo da culpa e responsabilidade em Heráclito seguindo a interpretação heideggerlana implica traçar o longo caminho percorrido até poder alcançar a interpretação dos fragmentos do pensador grego. Esse caminho segue a questăo do ser pelo fio condutor da temporalidade e e frente ao ser que a questāo da culpa e responsabilidade pode alcançar uma elucidação hermenêutica adequada. Propomos abordar esse caminho dando ênfase à paulatina elaboração de uma concepção de linguagem, claramente articulada no âmbito de $\mathrm{SZ}^{1}$ e reelaborada no confronto com a tradiçāo filasófica ocidental e com a obra poética. Ora, o lugar explícito em que a questäo da culpa/dívida aparece, mostrando o enraizamento da linguagem e do discurso na vida fáctica, é na análise do fenômeno da consciência, nos $\$ \$ 54-60$ de SZ. Vejamos de que forma o testemunho da voz da consciência é analisado e quais estruturas existenciais estão implicadas aí.

A analitica existencial levada a cabo na Primeira Secçāo de SZ se restringe a ser uma análise preparatónia dos fundamentos do Dasein, ${ }^{2}$ Foi dentro dessa deljmitaçäo que se tematizou, inicialmente, a abertura constitutiva do ser do "al", cujo esclarecimento produziu a interpretaçāo provisória da constituição fundamental do Dasein como ser-no-mundo. A estrutura da mundanidade, enquanto significảncia, revelou-se ligada com o projeto da compreensão, enquanto abertura. As estruturas constitutivas da abertura são co-originárias: a compreensão/explicitação, a disposiçăo e o discurso. Esta análise provisória, na medida em que não aborda a estrutura existencial da cura no seu sentido mais originário (a temporalidade), permanece abstrata. A análise dos fenômenos da compreensão/explicitação, da disposiçăo, da decadência e do discurso, assim como da angústía, da cura, da realidade e da verdade somente encontrarão uma explicitação mais completa quando se alcançar a tematização do ser do Dasein na estrutura da cura enquanto temporalidade. Por isso, o discurso é objeto de uma análise provisória, em que não aparece o fenômeno da cura, e de igual modo não é tematizado o enlace entre discurso e temporalidade (cf. § 68). Isto requer uma análise ulterior, que se defronta com a problemática da explicitação do que constitui o Dasein como si-mesmo, como caminho da determinação do ser do Dasein. Este caminho passa pelo exame da possibilidade do Dasein como ser-para-a-morte (\$§ 46-53), defronta-se com o testemunho đa consciência como um poder-ser em sentico próprio (\$§ 54-60) e desemboca na temporalidade como sentido ontológico da cura (\$§ 61-66).

Heidegger conclui o § 44 e a Primeira Secçăo de SZ com um questionamento relevante:

"Mas setá que com o fenômeno de cura é aberta a constituiçăo ontológico-existencial mais originária do Daseín? Será que a multaplicidaçe estrutural, que se encontra no fenômeno da cura, oferece a totalidade mais criginária do ser do Dasein fáctico? Será que a irivestigação feita até aqui jâ ganhou a perspectiva do Dasein como todo?" (SZ, 230).

1 Veja chave de abreviaturas das obras de Heidegger na bibllografia. Para a notaçâo bibliográfica, utilizamos a abreviatura da obra segulda de vírgula e aùmero da página correspondente.

2 Optamos por manter o termo em alemâo, ainda que pudesse ser, insuficientemente, traduzidio por ser-af, existente humano ou presença (opçäo escolhida pela tradução da SZ para o portuguess). 
Este mesmo questionamento é retomado no $\S 45 .^{3}$ Esse parágrafo, que abre a Segunda Secçāo de SZ, tem uma funçāo retrospectiva e prospectiva, pois apresenta um resumo das principais aquisiçõès alcançadas $\theta$ retoma a questão central do sentido do ser. Com isso já fica indicada a resposta às interrogaçōes sobre a suficiência ou nễo do fenômeno da cura para a elaboraçāo da ontologia fundamental: "a análise existencial do Dasein, até aqui realizada, nâo pode pretender originariedade" (SZ, 233). Outra modo de responder negativamente suas interrogaçôes aparece assim:

"T... a estrutura da cura, e a caracterjzamos como uma estrutura originária no sentido do
próprio Dasein, o qual naturalmente (quero sublinhar explicitamente) näo se revela como a
última conexáo do Dasoin mas, por assim dizer, é o penúltimo fenómeno para poder avan.
çar na autêntica estruzura do Dasein" (GA 20,406).

Sendo o fenómeno da cura o penúltimo, o úlitimo é aquele que se revelar como sendo o sentido da cura, ou seja, a temporalidade ${ }^{4} \mathrm{E}$ a Segunda Secção de SZ, como retomada, ampliaçâo e aprofundamento da analitica preparatória e provisória do Dasein, tratará do fenômeno da temporalidade. Contudo, o motivo que perpassa toda análise da temporalidade e lhe dá sua especificidade, è um só: "a originariedade" (SZ, 231). A passagem do penúltimo fenômeno para o último, da cura à temporalidade, implica uma interrupçāo da co-originariedade (Gleichursprüngilchkeit) dos existenciais e o surgimento de uma nova dimensāo: o aprion, o origjnário.

Para que a elaboração da questão ontológica fundamental seja oniginária, duas condiçరెes são indispensáveis: "propriedade (Eỉgentlichkeit) e totalidade (Ganzheit)" (SZ, 233). Para essa nova tarefa, faz-se necessáno retomar o procedimento metódico do círculo hermenêutico elaborado no $\$ 32$, possibilitando a elaboraçào de uma fenomenologia do tempo enquanto fenomenologia hermenêutica. Em função disso, a elaboração e apropriação de uma compreensão, como um modo possivel de explicitação, não se faz fora do "conjunto dessas 'pressuposições', o qual denominamos de situaçăo hermenêutica" (\$Z, 232), a qual comporta os três momentos constitutivos de toda explicitação: o pro-pósito, a pros-pecção e a ante-cipação. A descoberța da cura permitiu a aquisição de uma noção que funda a situação hermenêtica e nos permite efetuar uma interpretaçăo dos elementos que se apresentam ai: o pro-pósito (a cura), a pros-pecção (o poder-ser que compreende e no qual está em jogo seu próprio ser) e a ante-cipaçăo (poder-ser adiante de si mesmo). Com esses elementos, trata-se então de poder desenvolver a questão do poder-ser do Dasein como um todo e em sentido próprio. O poder-ser-todo (Ganzseinkönnen) é fornecido pelo conceito ontológico da morte enquanto serpara-8-morte e o testemunho de um poder-ser-próprio é fornecido pela consciência (Gewissen), que chama cada um para esse "poder-ser-completo próprio". Graças a esse "poder-ser-completo próprio do Dasein, a analitica existencial se assegura da constituiçāo do ser originário do Dasein" (SZ, 234), como modo da cura e também garante 0 "solo fenomenalmente suficiente para uma interpretação origi-

3 Encontramos o mesmo procedimento de parada metódica e de transição no $\S 33$ de GA 20.

4. Com Heidegger, poderiamos também respondar que o último fenômano á o ser, como postula (cf. GA 20, 422-423). 
nária do sentido de ser do Dasein" (SZ, 234). E entảo, a partir da temporalidade, faz-se necessário uma repetição da primeira analítica do Dasein, de modo que "as estruturas ontológicas do Dasein, anteriormente conquistadas, devem ser, retroativamente, postas a descoberto na direçâo do seu sentido temporal" (SZ, 234). Nessa repetiçâo interessa-nos examinar os desdobramentos relativos à linguagem e ao discurso, visando apreender o caráter temporal đa concepçâo de lógica presente no pensamento de Heidegger no período de elaboraçâo de SZ. Fica então ciaro que a descoberta da unidade originána da cura consiste na temporalidade e isso determina as relaçōes desta com linguagem e discurso, permitindo formular a questão sobre a temporalidade constitutivo do próprio discurso, para além da organizaçāo lingüistica do tempo enquanto tempo do verbo. A tese heideggeriana vai na direção de mostrar que o discurso é em si mesmo temporal na medida em que se funda na unidade extática da temporalidade (SZ, 349-350).

Os laços entre inguagem e temporalidade se mostram dentro do projeto da elucidaçăo da compreensão ontológica constitutiva do ser do Dasein. Nessa compreensão dá-se o caminho para a elucidaçâo da questāo do sentido do ser em geral, dentro do horizonte do tempo.

O primeiro passo nessa análise defronta-se com o fenômeno do Dasein como ser-para-a-morte ( $\$ \S 46-53$ ). Nessa análise se alcança um importante resultado a respeito da possibilidade mais própria do Dasein "como a [possibilidadel da impossibilidade da existência em geral" (SZ, 262), de modo que essa possibilidade enquanto irremissivel, sendo a mais própria, arranca o Dasein do impessoal e o situa enquanto singularidade, "O antecipar à possibilidade irremissivel obriga 0 ente que antecipa à possibilidade de assumir seu mais próprio ser a partir de si mesmo e dele mesmo" (SZ, 263-264). Antecipando a possibilidade da impossibilidade, antecipaçăo que năo se funda em nenhum fato empírico mas na angústia que abre a ameaça que cai sobre o Dasein, esse pode se desvencilhar do impessoal. É esse cogito tanatológico que permite uma passagem das formas inauténticas do discurso, como a ambigüidade, a falatório e a publicidade (analisadas nos §§ $35-38$, especialmente SZ, 173), onde é possivel se falar da morte como a morte de qualquer un e de ninguém, para o discurso que năo encobre o próprio e o singular, o insubstituível do ser-para-a-morte mais próprio. E esse discurso se dá em meio à angústia, como fenômeno que abre o Dasein, tanto para si mesmo quanto para os entes e para o ser, de modo privilegiado (SZ, 253; 266).

O segundo passo no enlace entre a temporalidade originária $\epsilon$ a linguagem encontramos no testemunho da voz da consciência como um poder-ser em sentido próprio, onde, através da análise do clannor da consciência e da "voz da consciência", são retomadas todas as estruturas fundamentais do discurso (SZ, \$§ 54-60). A análise fenomenologia da consciência (Gewissen) mostra que sua constituição profunda se dá como clamor (Ruf), "O clamar é um modo do discurso" (SZ, 269), que aclama o "Dasein para o seu poder-ser-si-mesmo mais próprio e isso no modo de conclamar o seu ser/estar em débito mais próprio" (SZ, 269). A voz da consciência é aclamaçăo (Anruf) e conclamação (Aufruf) ao mesmo ternpo (SZ, 269). 0 Dasein nâo é aclamado apenas pela intransigência do outro, mas é confrontado 
consigo mesmo. É dentro da conclamaçăo que o Dasein compreende sua capacidade de existir, enquanto capaz de escolher.

Heidegger introduz a problemática da consciência em busca de um testemunho que não venha de fora, mas que se enraiza no prớprio Dasein e que possa dar a compreender un poder-ser-si-mesmo próprio. Esse testemunho é buscado no fenômeno da voz da consciência, năo como uma descrição psicológica, uma interpretaçäo teológica, uma explicação científica, uma consideraçâo moral ou uma opiniâo empírica, mas como um fenômeno ontológico enquanto "fenômeno origrinário do Dasein" (SZ, 268), isto é, como um existencial. Essa tomada de posiçāo sobre o lugar da consciência é fundamental para uma correta avaliaçảo da originalidade da análise heideggeriana desse fenômeno: a consciência é um modo particular do compreender, e sua elucidação permite melhor apreender 0 sentido existencial do compreender. Deste modo, o fenómeno da consciência situa-se no âmbito do fenômeno da abertura do Dasein, com as suas modalidades características (disposiçāo, compreensāo, discurso e decadência), sendo que duas noçōes centrais săo submetidas à elucidaçăo fenomenológica: a voz da consciência no modo da aclamaçăo e da conclamação, que remete ao fenômeno do discurso, que aqui é redimensionado, retomando a análise do escutat/silenciar levada a cabo no $\$ 34$ de $\mathrm{SZ}$ e o fenômeno aparentemente enigmático do ser/estar em dívida.

Caracterizando a consciência como clannor (Ruf), e esse como um modo do discurso que articula a compreensibilidade, Heidegger busca romper com o "insuficiente ontológico-antropológico de uma moldura de faculdades da alma classificadas ou de atos pessoais" (SZ, 272) e igualmente "ultrapassar o impessoal e a interpretaçăo pública do Dasein [...]" (SZ, 273). Ora, esse modo do discurso que se dá no clamor da consciência apresenta-se de modo enigmático. Se tomamos a noção de discurso elaborada no $\$ 34$ de $\nwarrow$ Z, com suas trés dimensões constitutivas (referencial, poética e conativa), observa-se, em primeiro lugar, que o clamor da consciência é um điscurso "sem objeto", sem referencial, pois o aclamado é o próprio Dasein, enquanto modo de ser-no-mundo, isto é, sem nenhum conteúdo.

"O próprio-impesscal é aclamado para o si-mesmo. Contudo, näo lé] o si-mesmo que se pode tornar 'objeto' de avalieçăo, nio a si-mesmo que se empenha com cutiosidade sem descanso e inconsistente na dissecaçẫo de spa 'vida interior' e nẫo o si-mesmo de uma cupidez 'analitica' de olhar estados da alma e seus fundos. A aclamaçāo do si-mesmo no próprio-impessoal nâo impôe-se para si mesmo om um interior a fim de se dever trancar para o "mundo extetior"' (5Z, 273).

Em segundo lugar, o clamor da consciência enquanto função poética, ou seja, a mensagem, o que a consciência declama para o aclamado, revela-se paradoxal:

“O clamơ nầo pronuncia nada, nẩo fornece nenhuma informaçăo sobre acontecimento̊ do mundo, nada tem para contar. Mutto menos pretende iniciar, no si-próprio aclamado, uma 'conversa consigo mesmo'. Nada é de-clamado para o si-mesmo aclamado, mas leste] ê conclamado para ele mesmo, isto é, para o seu joder-ser mais prôprio" (SZ, 273).

O clamor da consciência, nâo sendo nem constatativo e nem narrativo, também nâo se pöe como um diálogo interior, mas fundamentalmente veicula uma mensagem performativa: "[...] enquanto conclamação de seu poder-ser mais pró- 
prio, o clamor é uma 'pro'-clamação (para 'adiante') do Dasein em suas possibilidades mais próprias" (SZ, 273).

Em terceiro lugar, o clamor da consciência enquanto funçăo conativa, ou seja, a comunicaçâo com o outro, mostra-se também paradoxal, pois "O clamor dispensa qualquer verbalização. Ele não vem primeiro a palavras e, não obstante, não permanece nada menos do que obscuro e indeterminado. "A consciência discursa apenas e sempre no modo do silenciar" (SZ, 273).

O caráter estranho e paradoxal do clamor da consciência enquanto discurso é acrescido pela resposta à pergunta acerca de quem clama. Nào é suficiente a resposta de que "na consciência, o Dasein clama por si mesmo" (SZ, 275). Precisamente no núcleo do si mesmo, da mesmidade (Selbstheit) e do mais familiar, Heidegger introduz a voz enquanto "força estranha que se ergue para dentro do Dasein" (SZ, 275).

\begin{abstract}
"O clamor justamente nấo e e nunca $\mid$ | $\mid$ planejado, nem preparado, nem voluntariamente cumprido por nós mesmos. 'Isso' clama contra toda espera e mesmo contra toda vontade. Por outro lado, o clamor, sem dúvida, năo provém de um outro que é/está no munco junto comigo. O clamor provém de mim e, no entanto, por sobre mim" (\$Z, 275).
\end{abstract}

Esse familiat/estranho, que provém de mim e ao mesmo tempo se apresenta como uma alteridade, se for interpretado segundo as explicações biológicas, sociológicas, teológicas ou psicológicas, nảo respeitaria o dado fenomenal central: "que o clamor provém de mim e, no entanto, por sobre mim" (SZ, 275). Essa alteridade que me pertence e ao mesmo tempo não está no meu domínio, constitui o ponto central de toda análise heideggeriana da consciência. Fsta voz que me conclama é estranha e nisso pode me arrancar do impessoal, libertando-me para a singularidade insubstituivel. Diz Heidegger:

"O clamor năo relata acontecimentos, clama também sem nenhuma comunicaçắo. $O$ clamor fala no modo estranho do silencjar/caler. $\mathrm{B}$ dessa forma somente porque o clamot năo aclama $\mathrm{o}$ aclamado para o falatório público do impessoal mas sim para dele sair e passar para a silsnciosidade do poder-ser existente" (SZ, 277).

Deste modo fica claro que o clamor da consciência não se define por algum conteúdo empirico ou por fundar-se na alteridade de um semelhante ou de um poder transcendente, mas sim se dá como angústia que possibilita o poder-ser mais próprio do Dasein. Ora, se é na angústia que se mostra 0 fenômeno da cura, Heidegger conclui que "a consciencia revela-se como clamor da cura" (SZ, 277). Fica em suspenso a questăo acerca daquilo que o clamor da consciência dá a compreender, ou seja, as modalidades de escuta da voz da consciência. Ora, Heidegger aponta para o fato de que "a 'voz' da consciência fala de 'débito" (SZ, 280).

O exame do fenômeno do débito/culpa (Schuld), desenvolvido de forma extremamente complexa, constitui o centro da análise heideggeriana da consciência. Distinguindo as várias acepçōes da expressão "estar em débito/culpado", Heidegger propōe que "a idéia de 'débito/culpado' é concebida a partir do modo de ser do Dasein" (SZ, 283), o que requer uma formalização que exclua os fenômenos vulgares de débito referidos ao ser-com os outros na ocupação. Esta tomada de posição na đireção de uma interpretação ontológica do đébito retira de cena a 
possibilidade da ética como filosofia primeira. Ou seja, o fenômeno do débito deve ser elucidado para além da noçăo de falta (Mangel). Ai Heidegger introduz algo surpreendente: a interpretação existencial do ser/estar em débito como tendo um caráter de não: "ser-fundamento de um ser determinado por um năo, isto é, serfundamento de um nada" (SZ, 283). Isto significa que o ser do Dasein se constitui a partir de um nada fundante enquanto débito origináno, possibilitador de todos os tipos de falta e débitos. E deste modo, "em sua essência, a cura está totalmente impregnada pelo nada" (SZ, 285), caracterizando-se assim a determinaçäo existencial do débito como ser-fundamento de um nada. É isso que significa dizer que o Dasein é/está em débito. Contudo, não fica esclarecido qual é o caráter de não desse nāo. Aqui Heidegger formula uma questâo relativa a um dos mais obscuros problemas da filosofia: qual é o estatuto do não? Aponta-nos que as condiçōes ontológlcas do nada só podem ser alcançadas pelo esciarecimento da questão sobre o sentido do ser em geral. "Apesar disso, o sentido ontológico da nadidade (Nichtheit) dessa nulidade (Nichtigkeit) existencial permanece obscuro. Mas isso vale também para a essência ontológica do não em gerâ"' (SZ, 285). Sabemos que a questäo sobre o sentido ontológico do nada continuará obscura para Heidegger, assim como a questão sobre o sentido do ser e uma questăo poderá lançar luz sobre a outra a partir da formulaçẫo da noção de diferença ontológica, onde se vislumbra que o ser se dá sempre como um nada de ente, ou seja, o ser que é não pode ser. "Ser não pode ser. Se fosse (ser), não mais permaneceria ser, mas senia um ente" (GA 9, 479).

Mesmo sem elucidar todo alcance deste nada fundante, a análise desse fenômeno nos revela que o Dasein, enquanto projeto, é essencialmente um nada enquanto aquilo que está adiante de si mesmo e nisto permanece sempre aquém de suas possibilidades. De outro lado, o Dasein "nunca existe antes/diante de seu fundamento, mas sempre e somente a partir dele e enquanto ele. Ser-fundamento diz, portanto, nunca poder se apoderar do ser mais próprio em seu fundamento" (SZ, 284). Esse é o embaraço e a ambigüidade em que o Dasein se encontra quando rompe com o modo impessoal de existe̊ncia e se defronta com o clamor da cura, que clama, na estranheza, a si mesmo para assumir seu poder-ser mais próprio. "Compreendendo o clamor, o Dasein é sujeito a/servo de sua possibilidade de existência mais própria. Ble escolheu a si mesmo" (SZ, 287). Ouvir essa aclamaçăo equivale a poder-ser/estar em débito mais próprio, ou seja, querer-ter-consciência como modo de ser responsável.

O resultado da elucidação do fenômeno da voz da consciếncia enquanto testemunho do poder-ser em sentido próprio do Dasein nos revelou que o querer-terconsciência é um modo de abertura do Dasein, na triplice estrutura da compreensão, disposiçāo e discurso. A compreensão se revela no projetar se para possibilidades factuais cada vez mais próprias do poder-ser-no-mundo. A disposiçăo se revela no clamor da estranheza do Dasein consigo mesmo em sua singularidade, no modo da angústia da consciência. $O$ discurso que Heldegger examina mais detidamente revela um testemunho em que o clamor da consciência é recusa de todo e qualquer contradiscurso. $\mathrm{O}$ clamor da consciência não se điscute, pois 
“... é um silêncio. $O$ discurso de consciência nunca chega à comunicaçāo. A consciência só clama em silènoio, isto é, o clamor provèm da mudez da estranheza e reclama o Dasein conclamado como para aquietar-se na quietude de si mesmo. í só na silenciosidade, portanto, que o querer-ter-consciêncla compreende, única e adequadamente, este discurso silencioso" (SZ, 296).

Corn isto fica claro que os modelos de comunicação dialógica sẵo insuficientes para apreender o fenômeno originário do discurso, pois ficam no nivel do fenômeno derivado e com isso deixam de fora o fenômeno da abertura originária do Dasein que se mostra na compreensāo/disposição/discurso. Dito de outro modo, dando ênfase à linguagem pública, permanecemos presos ao modo impessoal de ser e com isso não se alcança o modo privilegiado de abertura do Dasain denominado por Heidegger como decisâo (Entschlossenheit).

Heidegger define então a consciência "[...] pola disposiçăo da anguistia, pela compreensão enquanto projetar-se para o ser/estar em débito/culpado mais próprio e pelo discurso enquanto silenciosidade" (SZ, 296). E esses três aspectos do testemunho da consciência encontram um denominador comum no termo introduzido por Heidegger: a decisāo.

\begin{abstract}
"Chamamos de decisto esta abertura privilogiada e própria, testemunhade por sua conscí́ncia no próprio Dasein, o projetar-se slienctoso e prestes a angustiar-se para o ser/estar am débito/culpado mals próprio" (SZ, 296-297).
\end{abstract}

Esta nova estrutura existencial, assim como toda passagem do impessoal para o autēntico e próprí, não tem um caráter voluntarista ou decisionista, mas situase no mesmo plano da abertura (Erschlossenheit) do Dasein, definida no $\S 44$ de SZ como a verdade originária da existência. A decisão implica um giro a mais na verdade originária em direção do mais próprio. "Com a decisão é conquistada, agora, a verdade mais originária do Dasein porque a mais própria" (SZ, 297). Com a tematização da decisão, os dois outros modos de ser da abertura, o serdescoberto (Entdecktheit) das coisas na dupla modalidade da manualidade (Zuhandenheit) (os utensilios) e do ente subsistente (Vorhandenheit) (os objetos), e a abertura do mundo (Eirschlassenheit) como existência nas modalidades da compreensão e como verdade existencial do Dasein, se modificam. Essa modificação se faz a partir da decisão enquanto verdade existencial mais própria e a partir do ser si-mesmo mais próprio, incidindo na relaçăo com os entes intramundanos e com os outros. "Essa abertura própria, porém, modifica, de forma igualmente orlginária, a descoberta do 'mundo' nela fundada e a abertura do co-Dasein dos outros" (SZ, 297). Deste modo, é somente a partir da decisão enquanto modo de ser do Dasein que se escolhe a si mesmo, que implica o ser si-mesmo próprio, a escuta do discurso silencioso do clamor da consciência e a verdade existencial mais própria, e que se funda a modo próprio de descoberta do mundo e o ser-com da preocupação com os outros.

“A partir do ser sil-mesmo próprio da decisāo é que nasce primeiramente a convivência ern sentido próptio, năo porém dce compromiseos ambíguos e invejosos e das confraternizacōes tagarelas no impessoal e no que, impesscalmente, se queira empreender" (SZ, 298).

A decisão, enquanto estrutura existencial, como modo de ser mais próprio do Dasein, se caracteriza por uma determinação própria que não se confunde com 
algum ato voluntário calcado num saber sobre o que se quer, mas se pōe no decisivo (Entschluss) concreto, existenciário. "A decisão só está segura de si mesma enquanto o decisivo" (SZ, 298). Repete-se aqui a oposição de dois planos: de um lado a decisão que se pōe na determinação do decisivo, que ouve o clamor da consciência $\theta$ o ser/estar em débito mais próprio, e de outro lado a indeterminaçấo da indecisāo que se submete à ditadura do impessoal. Dois outros planos também aqui se cruzam: o plano das estruturas existenciais enquanto modos de ser do Dasein, portanto, um plano ontológico, e o plano das opções existenciárias, fácticas, dadas no plano ôntico. Estes dois planos até aqui sempre foram cuidadosamente distinguidos por Heidegger. Agora, através da noção do decisivo, Heidegger realiza a junçăo das estruturas existenciais com as opçōes existenciárias. A aproximação destes dois planos foi esboçada no § 42, como uma possibilidade de confirmar as estruturas existenciais (a estrutura fundamental da cura) através de testemunhos pré-ontológicos e existenciários (cf. SZ, 199-200). Aquilo que então era apenas uma possibilidade, aqui se apresenta como uma necessidade. Assim podemos compreender o que Heidegger quer dizer com a frase: "A decisāo só está segura de si mesma enquanto o decisivo". A decisão não significa um retirar-se do mundo, ficar isolado num eu solto no ar, mas enquanto ser-si-mesmo mais próprio e lançado, "só pode projetar-se para possibilidades fácticas determinadas" (SZ, 299). 0 decisivo, enquanto determinação do impessoal, carrega consigo o mundo e ao mesmo tempo, enquanto abertura da decisāo, propicia a transparência do $\mathrm{Da}$ sein. "O decisivo é justamente primeiro o projetar e determinar que, cada vez, abrem as possibilidades fácticas" (SZ, 298). Deste modo, o Dasein, enquanto determinação que descobre o possivel em seu fato, apreendendo seu poder-ser mais proprio a partir do impessoal, implica-se na "realidade" enquanto decisivo.

A determinação existencial do Dasein permite a Heidegger introduzir um último fenômeno existencial: a situação. ${ }^{5} \mathrm{~A}$ decisão requer sempre uma situação, que remete de algum modo para a espacialidade existencial. Toda decisão requer um lugar onde o Dasein decidido realiza-se como determinação existencial. A situaçāo, enquanto fenômeno existencial, näo se confunde com as circunstâncias e as contingências que determinam o quadro externo das açōes, mas "assim como a espacialidade do ai se funda na abertura, assim a situação tem seus fundamentos na decisão" (SZ, 299). Deste modo, a situação recebe seu sentido somente a partir da decisão e do decisivo, pois "a decisão conduz o ser do aí à existência de sua situação" (SZ, 300).

O fenômeno existencial da situaçăo protege o clamor da consciência enquanto decisão contra um duplo perigo, na medida em que "a situação permanece essencialmente fochada para o impessoal" (SZ, 300): contra o perigo de tomar o clamor da consciência como un ideal vazio de existência jogando o Dasein em culpabilizaçōes intermináveis, e contra o perigo de tomar a decisāo como um hábito vazio ou uma veleidade indeterminada para agir de tal ou qual modo. Deste modo, a noção heideggeriana de decisão não funda nem uma filosofia da vontade e nem uma filosofia da açâo. Heidegger declara explicitamente que quer evitar o conceito de ação, pois tem a desvantagem de privilegiar a atividade em detri-

5 Heidegger introduzitu a noçăo de situaçāo no Curso de 1919-1920 (GA 58, 62-63). 
mento da passividade e introduz a oposição entre o teórico e o prático, "Năo é tomando conhecimento que a decisâo imagina uma situação, mas ela já se coloca em uma situação. Como decidido, o Dasein já age" (SZ, 300).

Deste modo, como resultado da análise do fenómeno da consciência, tornouse claro que o clamor da consciência para o poder-ser mais próprio do Dasein enquanto decisão "proclama a situação" (SZ, 300), e nisto se revela a dimensão onginána da compreensāo/disposiçăo/discurso, "como o projetar-se silencioso e prestes a angustiar-se para o ser/estar en débito/culpado mais próprio [...]" (SZ, 301).

Depois de passarmos pelo exame da possibilidade do Dasein como ser-para-amorte (\$§ 46-53) e defrontando-nos com o testemunho da consciência como um poder-ser em sentido próprio ( $\$ \S 54-60$ ), alcançamos o terceiro momento da explicitação do ser do Dasein como poder-ser todo em sentido próprio: a temporalidade como sentido ontológico da cura (\$\$ 61-66). A análise do fenômeno da temporalidade permitirá um quarto momento, a temporalidade e a cotidianidade (\$\$ 67-71), onde encontramos a tematização do enlace entre discurso e temporalidade ( $\$ 68$ ). 0 que aqui cabe ressaltar è que o fenỏmeno da consciência como ser/estar em débito permite a passagem para a determinação do sentido ontológico da cura enquanto temporałidade. Não é demais frisar que toda a análise do fenômeno đa voz da consciência visa preparar a adequada determinaçāo do estatuto ontológico do "sujeito", da res cogitans, ou seja, do ser do Dasein. Esta mesma temática aparecerá em Heráclito, segundo a leitura heideggeniana, especialmente nos fragmentos 45 e 50 .

\section{2 - Em busca do Lógos impensado na lógica ocidental}

A lógica, segundo a interpretação heideggeriana de Heráclito, consiste em manter-se expressamente no interior do saber do Lógos, mas isso sempre parece estranho ao homem. Para poder alcançar este âmbito em que o lógos humano advenha à sua essência como acordo (homologein), é necessário realizar o passo atrás da lógica aristotélica para o Lógos de Heráclito. Ora, "este saber preparatório do Lógos originário é a 'lógica' originária. Aqui 'lógica' significa: manter-se no interior do Lógos enquanto o presente do recolhimento originário" (GA 55, 358359). No percurso de Heidegger, podemos situar quatro momentos especificos do passo para trás em busca do mais originário, antes de alcançar o pensar đo Ereignis, acontecimento/apropriaçāo, patamar próprio do Heideggger tardio. A estratégia heideggeriana de busca do solo fenomenal adequado para aicançar o originário é sempre a estratégia đa preparaçâo em vista de poder manter-se naquilo que é o mais digno de ser pensado: o ser. Em Heráclito, a palavra fundamental que nomeia esse âmbito origináno é precisamente Lógos.

Os cursos e os textos de Heidegger permitem situar estes quatro momentos distintos da sua investigação sobre a lógica e o problema do lógos: 


\section{1 - A primeira lógica heideggenana}

Fontes: Lógica. A questäo da verdade, WS 1925/26, GA 21; Ser e tempo, 1927; Os problemas fundamentais da fenomenologia, SS 1927, GA 24.

O primeiro momento da investigação heideggeriana sobre a lógica gira em tomo da crítica ao psicologismo e da elucidaçāo da questäo da verdade. Trata-se da busca de uma lógica filosofante, orientada pelo paradigma das Investigaçōes lógicas de Husserl. Este desenvolvimento corresponde ao inicio do ensino em Marburg (inverno de 1923/24) e se estende até a época da publicação de SZ, 1927, quando formula a noção de diferença ontológica (GA 24, 23).

O Curso do inverno de 1925/26, Lógica: a pergunta pela verdade, contém seu primeiro conceito de lógica: a lógica se define como investigação da função desvelante do discurso humano em vista da verdade. A elaboraçäo da lógica filosofante será incorporada em SZ, sendo que é em Aristóteles, lido de uma maneira radical, que Heidegger encontrará o caminho para interrogar as três teses clássicas: a o enunciado seria o lugar da verdade; $b$. a verdade consistiria na adequaçâo do pensamento e do ente; c. Aristóteles seria o autor destas afirmaçōes.

\section{2 - A segunda lógica heideggeriana}

Fontes: Fundamentos metafisicos da Lógica a partir de Leibntz, SS 1928, GA 26; Os conceitos fundamentais da metafísica: mundo, finitude e solidâo, WS 1929/30, GA 29/30; Sobre a essencia da liferdade humana, SS 1930, GA 31.

O segundo momento da investigaçāo heideggeriana sobre a lógica corresponde ao último curso dado em Marburg: Os principios metafisicos iniciais da Lógica, partindo de Leibniz, no verāo de 1928. É neste Curso que Heidegger empreende uma primeira interpretaçâo critica e sistemática de SZ, realizando-se assim a primeira viravolta (Kehre) no seu pensamento. Sua leitura de Leibniz consiste em mostrar que a lógica leibniziana é solidánia de uma metafísica especifica, a monadologia, alcançando esta formulação: "A lógica fundamenta-se na metafísica e não é nada mais do que a metafisica da verdade" (GA 26, 132).

Se a primeira lógica já havia mostrado que a idéia de verdade contém mais que um laço estabelecido entre as representaçōes ou que a análise do juizo como synthesis neomaton não se restringe à noçäo de adaequatio rei et intellectus, ou seja, que o lógos hermenêutico precede o lógos apofântico, a segunda lógica abre o periodo metafisico do pensar heideggeriano, realizando a passagem do problema do sentido do ser para o problema da verdade do ser.

\section{3 - A terceira lógica heideggeniana}

Fontes: A lógica como questão da linguagem, SS 1934, näo publicado. Anotações de H. Weiss (1991) (W); "Hinos 'Germanien' e 'Der Rhein' de Hölderlin", WS 1934/35, GA 39; "Hino 'Andenken' de Hölderlin", WS 1941/42, GA 52; "Hino 'Der Ister' de Hölderlin", SS 1942, GA 53; "Contribuiçôes à filosofia”, GA 65.

O terceiro momento da investigaçăo heideggeriana sobre a lógica pode ser situado no Curso do verāo de 1934, Sobre a lógica como pergunta pela linguagem. 
Contudo, este Curso ainda não foi publicado, mas dispomos das anotações de $\mathrm{H}$. Weiss (1991) (W).

Um testemunho de Heidegger acerca deste Curso diz:

\begin{abstract}
"Somente vinte anos após o escrito de habilitação me atrevi, num curso, discutir a questão da linguagem (Sprache). Isso aconteceu na mesma epoca em que comuniquei em cursos as primeiras interptetaçōes dos hinos de Hölderlin. Durante o semestre de verâo de 1934 dè um curso com o título: 'Logica'. De fato, era uma meditaçáo sobre o lógos na qual indagava acerca da essència da linguagem. No entretanto, passou-se ainda quase uma década até que estivease em condiçôes de dizer o que pensava - ainda hoje a palavia apropriada falta" (US, 93).
\end{abstract}

Este intervalo de dez anos é o que separa este terceiro desenvolvimento da lógica do curso sobre o Lógos de Heráclito (1944), que situamos como sendo sua quarta formulaçầo da lógica, onde alcança o limiar do pensar do Éreignis, que somente em Unterwegs zur Sprache efetivamente se desdobra. Năo t sem relevância que aqui se delineia uma explícita aproximação entre Hölderlin e Herácilto. Podemos ver que é através da interpretação da obra do poeta que Heidegger realiza uma preparaçâo para buscar a lógica originária em Heráclito.

Ora, e possivel encontrar no curso sobre Hölderlin, como o próprio Heidegger nos indica, aquilo que constitui sua indagação sobre a essência da linguagem. Podemos apontar, na "meditaçāo preliminar" (GA 39, §§ 2-7) à interpretaçāo dos hinos de Hölderlin, uma estrutura hermenêutica que permite um acesso possivel ao texto do poeta. $\hat{E}$ decisivo para tal observar que o dizer poétion se enraiza num poema antes do próprio poema, ou seja, numa disposiçâo fundamental (Grundistimmung). \& esta disposição fundamental que determina uma relação com o ser e ai situa-se a tarefa do filósofo: descobrir esta significaçäo metafisica fundamental. Podemos reconhecer nesta estrutura hermenêutica a estrutura geral do triângulo do ser-no-mundo tal como ja foi definida em Ser e tempo: anterior ao compreender/explicitar e ao discurso, mas igualmente originário, está a Befindilichkeit/Grundstimmung, (que podemos traduzir por disposição/disposição fundamental), mas que aqui é reforçada. Como em SZ, Heidegger salienta que a disposiçäo nâo é e nem deve ser entendida como afeto, sentimento ou estado d'alma. $\mathrm{O}$ que ocorre é que a definição adequada e positiva da Grundstimmung é correlata de uma definição de homem que ainda nāo existe. É entāo que Heidegger propōe uma definição, distinguindo quatro dimensôes essenciais: Entrückung zu den Gottern, Einrückung in die Erde, Welteroffung, Daseinsgründung (GA 39, 181), ou seja, exposição aos deuses, inserção na terra, abertura de mundo, fundaçăo de Dasoin. Esta estrutura pode ser tomada como a prefiguraçăo do que mais tarde Heidegger denominará de Geviert.

O caminho da compreensão da linguagem passa necessariamente pela poesia, pois é aí que se revela que nầo somos os proprietários da linguagem, mas é ela que nos possui (GA 39, 23). O caminho para a essência da poesia supōe a identificaçăo da Dichtung no poema. Se o poema é tomado como uma ativiđade da imaginaçăo produtiva, como é pensado na estética do gênio no romantismo e no que se sucede, entäo este nâo seria mais do que a manifestação da necessidade vital de um povo. Mas Heidegger considera, partindo do poein grego, que o poema enquanto poema é uma mostração especifica (GA 39, 30-41). 
O essencial é compreender que as modalidades e a origem última do fazer signo, que constitui a enunciaçāo poética, avança para uma nova dimensâo da linguagem nem mesmo entrevista $\mathrm{em} \mathrm{SZ}$. Toda doação de sentido remete para um arqui-signo, que Heidegger denomina Wink. Deste modo, a linguagem, como sistema de signos e de significância, faz signo em direção aos Winke, que constituem a linguagem dos próprios deuses. Assim, pode-se definir a poesia: Dichtung - Aushalten der Winke der Götter - Stiftung des Seyns/ "Poesia: suportar os signos dos deuses - instauração do ser" (GA, 39, 33).

$\mathrm{Na}$ poesia se realiza efetivamente o caráter "projetivo" da ontologia: "O ser é o que exige em nós criação para que nós tenhamos experiência" (GA 39, 251).

Será que tal definição da poesia, que orienta toda uma visão da linguagem e que nisto descortina uma "lógica" inteiramente nova, é sustentável? Para Heidegger é, na medida em que se aceite o paradoxo de uma instauraçâo do ser que parece se juntar com a realidade $e$ contudo nầo è a partir de um sujeito prometeico que ditaria suas condiçôes à realidade. É uma instauraçâo do ser onde não impera nenhuma dominaçāo do sujeito, mas exposição extrema ao próprio ser. 0 dizer poético torna-se o lugar de uma veemência ontológica, cuja violência deixa os humanos perturbados. Assim, a linguagem porta em si esta violência, que exprime a própria exposição ao ser.

"Na linguagem como tal se produz a extraposiçāo (Aus-elnandor-sotzung) do ser a do năoser, o fato de que as potências se erguem uma contra a outra, o resistir e o sucumbir neste combate, mas igualmente a banalizaçăo na indiferença do tudo-saber e do tudo-poder" (CA $39,66)$.

O fio condutor de todas as análises dos poemas de Hölderitn é sempre a questão da enunciação. Três enunciados estreitamente relacionados definem esta nova "lógica":

1. Hölderlin permite compreender o que é a essência da poesia;

2. A poesia define a essência da linguagem;

3. Na linguagem poética se realiza a fundação do Dasein.

Assim, pela linguagem o homem se torna o "testemunho do ser" e na linguagem pośtica se abre um mundo. Mas onde há mundo e linguagem também impera o perigo supremo: a ameaça do ser pelo nâo-ser, presente em tocas as ambigüidades da linguagem. O real perigo reside na tagarelice que vive da ilusão transcendental de que o ser já está sempre entendido e sabido (GA 39, 62). Outro perigo se encontra na proximidade com os deuses: poder blasfemar e com isto se pôt ao abrigo dos deuses, se proteger dos mesmos (GA 39, 66; 70).

A poesia e a linguagem também descrevem a constituiçăo fundamental do Dasein como histórico. Somos um "acontecimento de linguagem", năo apenas enquanto diálogo inter-humano, mas enquanto abertura orginária da temporalidade, abertura do tempo da história humana. É o próprio poema, enquanto lugar em que se dá esta abertura, que permite ao homem habitar o mundo. Contudo, a abertura deste diálogo nåo é fruto da iniciativa do homem, mas dos deuses. Săo eles que nos dirigem a palavra, e se existe um "a caminho da linguagem", é por causa deles e por sua iniciativa. 
Fazer parte do projeto criador/instaurador (stiftender Entwurf) (GA 39, 164) requer uma fidelidade ao ser como pressuposiçāo de toda e qualquer pertença, que remete à possibilidade de uma escuta originária do próprio ser. Assim, a abertura do Dasein ao ser que the é reservado e destinado, se faz nesta escuta, que emerge delimitada dentro de três modos de escuta:

1. a escuta divina: a misencórdia quahficada como Erhören;

2. a escuta dos mortais: a fuga, isto ê, nāo-escuta como Uberhören;

3. a escuta do poeta que tem seu lugar e sua qualidade de semideus.

Os deuses deixam partir a origem, os humanos voltam-lhe as costas no esquecimento e os poetas ouvem a origem originária em seu próprio surgimento e assim abrem a possibilidade de pensar esta origem (GA 39, 203).

Isto tudo implica passar para um outro pensar, qualificado por Heidegger como Andenken, que ultrapassa o registro da comunicaçāo considerado como informação ou troca de mensagem. Está no âmbito da saudação, que implica no reconhecimento da dignidade de uma essência. Heidegger denomina esta disposição fundamental como sendo a Gelassenheit/serenidade, que encontra na saudaçäo a sensibilidade fundamental da alegria que perdura. Ai se abre uma temporalidade privilegiada, a temporalidade festiva da festa.

"O festivo funda a co-pertença da alegria $e$ da tristeza. Mas para compreender esta co-pertença, é preciso aceitar que em toda disposiçāo fundamental fala a voz do ser" (GA 53, 72).

Ser é a condição de possibilidade de todo verbo, de todo agir e mesmo de todo silêncio. "O ser é o mais dito em todo dizer, pois o dizivel somente pode ser dito no ser" (GA 51, 63). Ou ainda, ser se oculta onde algo, o ente, se mostra, pois "o ser é o calar-se (Verschweigung) de sua essência" (GA 51, 64). E ainda mais, "pois o ser, enquanto calar-se, seria também a origem da linguagem" (GA 51, 66). Por isso, Heidegger poderá marcar a diferença ontológica nesses dois nivels da linguagem: "O ente é dito. O ser é calado" (GA 51, 77).

Isto tudo implica um deslocamento do conceito para se alcançar uma outra compreensão:

\begin{abstract}
"Compreender o ser quer dizer compreender o "tundamento". Com-preender quer dizer aqui 'ser compreendicio' no ser pelo ser (Ein-begniffen-sein). Compreender significa a cada vez aqui mutação de humanidade a partir de sua relaçäo essencial com o ser, mas primeiro que isto, a disponibilidade para esta mutaçăo, mas antes a preparaçấo desta dísponibllidade, mas antes, a atençăo para esta preparaçẫo e antes a incitaçá́o a uma tal preparaçáo e antes um primeiro recolhimento no ser" (GA 51, 93).
\end{abstract}

Esta outra compreensão, que implica uma outra e radical relaçăo com o ser, relação em que o Dasein se constitui no próprio constituir-se da relaçāo, ou seja, o ser é que possibilita todo agir e todo dizer do Dasein. Alcançar esse âmbito do ser é possivel na medida em que haja uma preparação que permita uma viravolta, que de uma posiçẫo de domínio se passe para uma posição de escuta e disponibilidade para o que se manifesta naquilo que silencia enquanto fundamento originário.

Em Holderlin se articula, como nos mostra Heidegger ao longo de sua leitura dos hinos do poeta, dois níveis: O sagrado (Heilig), prévio aos deuses e ao próprio divino, o poema anterior a todo dizer, o imediato, que se apresenta numa dupla 
tonação (Stimmung). É familiaridade, intimidade e doçura penetrante e ao mesmo tempo desterro, angústia e desamparo. O sagrado enquanto puro imediato ao mesmo tempo envolve e expulsa. Realizar a aproximaçâo do sagrado exige a tarefa que é própria do poeta $\theta$ o exercício desta mediação do sagrado pertence ao próprio Lógos. O poeta é aquele que ocupa a funçẫo de mediador, que muda o terror do imediato na doçura da palavra mediata e mediadora, abrindo assim o âmbito em que habitam os homens, segundo nivel. Que Hölderlin tenha enunciado este caminho entre o sagrado e o que funda o ser do homem, permitindo compreender a essência da poesia e nesta a essência da linguagem, nos indica os motivos da escolha deste poeta por Heidegger. Doutro lado, também já deve estar suficientemente claro que a culpa/divida e a responsabilidade não poderiam ser elucidadas adequadamente fora da questão do ser $e$ da linguagem. Na medida em que $O \mathrm{Da}$ sein se lança na sua verdade, na questâo do fundamento e do que the é próprio, defronta-se com algo que se lhe dá. Reconhecer e agradecer é o próprio trabalho da divida, do ser/estar em débito, momento de teceber o dom do ser. Ora, um dom somente se realiza no ato de ser recebido, e o poeta, no dizer poético, é aquele que mais apto se encontra para receber este dom, realizar esta passagem através do dizer essencial do poema, instaurando ser. Estes dois niveis - o sagrado e o dizer poético - recobrem os dois lógos que Heidegger nos apresenta em sua leitura de Heráclito. O primeiro Lógos, que escreve com maiúscula, é o silểncio prévio a toda palavra. Não se trata do inefável, mas a colheita/coleta, a unidade que precede todo dizer. Ora, este não-dizivel, o sagrado, se diz no dizer poético, sempre com o risco de se perder. O pceta é este semideus que enfrenta os riscos deste dizer que faz mediaçāo, resultando no mediato que é o próprio poema, ou seja, o segundo Lógos, o Lógos humano.

\section{4 - A quarta lógica heideggeriana}

Fontes: Lógica. A doutrina de Heráclito do Lógos SS 1944, GA 55.

\subsection{1 - O longo caminho para o Lógos originário}

O quarto momento da investigaçăo heideggeriana sobre a lógica situando-se no Curso do verão de 1944: Lógica. A doutrina de Heráclito do Lógos.

$\mathrm{O}$ acordo origináno, segundo Heidegger (GA 45, 19), presente jả em Aristóteles, é a palavra, nảo como convençấo, mas acordo, onde se apresentam os elementos:

a) a coisa oferecida;

b) o espaço entre a coisa $e$ o homem;

c) o homem em relação à coisa;

d) o homem em direção ao outro homem.

Ao traduzir interpretando o fragmento 123 (physis kriptesthai philei, "Natureza ama esconder-se") como "Das Aufgehen (aus dem Sichverbergen) dem Sichverbergen schenkt's die Gunst". "O emergir (desde o seio do velar-se) dispensa o favor ao velar-se" (VA, 263; cf. GA 55, 110), Heidegger nâo pretende simplesmente restituir o pensamento verdadeiro de Heráclito, mas o seu impensado. 0 impensa- 
do diz respeito à riqueza inominada de um pensar já pensado e que nos solicita como ainda incompreendida $\theta$ ainda por pensar. Ora, este impensado e năo nomeado na physis de Heráclito se encontra, segundo Heidegger, na aletheia ai năo nomeada. Por isso pode afirmar que "a alétheia é a essência da physis" (GA 55, 173) e "o Lógos é em si ao mesmo tempo um desvelar e um velar. Ele é a Alétheia" (VA, 213). Heidegger também frisa a relação interna de Lógos com Hèn Pánta (Um é Tudo) do final do fragmento 50, apontando que a interpretação corrente de que o Um é Tudo é aquilo que o Lógos anuncia não é adequada. Ou seja, o Hèn Pánta não é o que o Lógos diz mas é o modo como o Lógos desdobra seu ser. "Hén Pantá diz o que é o Lógos. Lógos diz como Hén Pantá se desdobra em seu ser. Ambos são o mesmo" (VA, 213). Essa inversăo na direçăo da interpretação, que não é o Lógos que diz o que é o Hén Pantá, mas sim esse é que diz o que é o Lógos, e por sua vez, o Lógos diz como o Hén Pantá se mostra em seu ser, aponta sempre, na interpretaçâo heideggeriana, para o Lógos oniginário enquanto Hén (Um), que tudo unifica, que reúne e recolhe o disperso, possibilitando o divino e o mortal, possibilitando o Lógos humano, a linguagem. É a partir deste originário que se funda o existir humano, pois a ética, segundo a fórmula de Heráclito, que resume todo o desenvolvimento de sua época, consiste em seguir Hèn Pánta (um: tudo; tudo: um), que por sua vez è o permanente. Importa primeiro conhecer este único-uno que unífica, mesmo podendo ser difícil de ser conhecido e até mesmo incognoscivel $\mathrm{e}$ apenas então se requer $o$ amor do belo e a força para $o$ alcançar.

Heidegger, insistentemente, nos alerta para a extrema dificuldade de se entrar no limiar do Lógos originário: "Longo è o mais necessário caminho para o Lógos originário" (GA 55, 375). Por outro lado, nos alenta para o caminho que ai se prepara, indicando que a passagem pelo legado de Heráclito se faz pela orientação do pensar que advém, o pensar do Ereignis (acontecimento/apropriaçāo). "A elucidação repousa na suposição do acontecimento-apropriação" (GA 55, 377). Deste modo, a quarta lógica heideggeriana aponta para uma relação essencial entre o Lógos de Heráclito e o pensamento do Ereignis, fomecendo o quadro conceitual indispensável para situar o pensamento desdobrado em Unterwegs zur Sprache (US). O retorno às palavras fundamentais do pensamento ocidental, na tentativa de sacar um Lógos mais originário que aquele que serve de base para a metafisica, é condiçăo necessária $e$ indispensável para realizar a transição para um outro pensar.

A quarta lógica repete aquilo que já está presente nos desđobramentos anteriores, em especial a oposição herdada da lógica formal e da lógica material, ou seja, a lógica das coisas e a lógica do pensamento. O pensamento calculante năo se move além destas duas lógicas, enquanto que um pensar preocupado em ultrapassar tal oposiçäo necessita se confrontar com o projeto fundamental de toda e qualquer lógica: buscar "aprender a pensar". Mas, "o que pensa e em que direção pensa o pensar quando apenas se pensa?" (GA 55,198$)$. Tal è a questão inicial de uma "lógica originária", que não se restringe apenas a fazer historiografia da loggica.

A fundaçäo grega da lógica surge na triade episteme physike, ethike e logike, atribuida a paternidade a Platão, segundo Sexto Empinico. Aceitar tal paternidade 
implica em se conformar com o destino ulterior da metafisica, que instaura uma relação essencial entre o legomenon e a idea, que permite pensar o ente a partir das idéias. As metafísicas posteriores, mesmo renegando Platão, repetem esse mesmo projeto metafisico.

O sintoma maior de tal projeto aparece no fato de que as determinaçôes mais gerais do ser sāo nomeadas "categorias" (GA 55, 255). A palavra 'categoria', mais do que a palavra lógos, acusa a ligaçäo entre ser e discurso. A "lógica" da metafisica é em primeiro lugar uma doutrina das categorias, sem que a própria metafisica possa compreender esta ligação. É o que se passa com Kant que, mesmo realizando sua revoluçăo copernicana no campo da lógica, não consegue ultrapassar a solidez desta ligaçâo entre ser e discurso. As três criticas na realidade săo três "Iógicas" que efetivam a passagem para a lógica transcendental. Esta passagem é decisiva para o pensamento pós-kantiano e permite o coroamento do desdobramento đa lógica gerada por Platão na Ciência da Lógica de Hegel. Desđe sua origem grega, a lógica é metafisica. Contudo, isto só sabemos graças a Hegel e depois deste não podemos ignorar que "o pensamento ocidental enquanto metafisica é no fundo o desdobramento da 'lógica"' (GA 55, 236).

Este desenvolvimento determina tambem a posiçăo do homem entre os demais entes: zoon logon echon, ou seja, o homem é um animal metafisico na medida em que é um animal 'lógico'.

Heidegger repete em vários momentos de seu Curso sobre Heráclito que a "lógica" é a metafisica do lógos. A realizaçăo hegeliana desta histónia igualmente coloca em evidência outro traço fundamental: a lógica decide igualmente acerca da constituiçăo onto-teo-lógica da metafisica, isto é, determina a estrutura e os limites do acolhimento da divindade na filosofia, na forma da causa suj. De igual modo, a lógica é igualmente a "ética" da metafisica, tomando ethos em sua acepção grega de habitar; a lógica define o habitar dos homens e dos deuses.

Partindo da realização lógica da metafísica, é necessário dar um passo atrás e colocar-se dois tipos de questōes: prospectivamente, o pensamento pré-platônico é apenas uma preparaçâo para o logos da metafisica? Podemos encontrar um lógos esquecido atrás do muro da metafísica? Retrospectivamente, o lógos da metafisica realiza seu último giro na vontade de potência de Nietzsche enquanto lógica da reflexão. Ora, é através desta lógica da reflexão que se funda o paradigma da subjetividade, próprio da modernidade que busca o fundamental último na solidez do sujeito epistêmico, auto-reflexivo e autofundado, reediçẵo da causa suf. A superação da forma moderna da reflexão, como metafisica da subjetividade calcada no lógos motafísico, exige um outro tipo de 'reflexäo', ao qual Heidegger se propõe buscar.

O caminho para este outro pensar năo segue o caminho hegeliano, de recusa da lógica reflexionante da esséncia para encontrar na imediatidade uma "lógica do ser", mas sim compreender de outro modo a "reflexảo", isto é, abnir o caminho para alcançar o mais profundo do pensar. Heidegger encontra isto nas palavras de Hölderlin:

Wer das Tiefste gedacht, Lebs das Labundigste.

Quam mecita o mais profundo, vive o mals vivo. 
Com tal referência a Hölderlin, Heidegger indica claramente que é este poeta quem realizou a abertura de um outro pensar que nāo o metafísico. No mínimo jả é afirmar que o pensar em sua profundidade já é amor (GA 55, 212).

\subsection{2 - A redescoberta do Lógos pré-metafisico: a superação do esquecimento do Lógos}

O enigma primeiro que é preciso enfrentar diz respeito ao que desde cedo Logos quer dizer para os gregos: "dizer, discorrer, enunciar, falar sobre". Contudo, esta não é a significação primeira da palavra e mesmo quando fixou-se a significação metafísica, ainda assim subsistiu algo da significação originária. Trata-se de poder superar este "esquecimento do Lógos" e interrogar-se não apenas sobre a paternidade da lógica (atribuida a Aristóteles, mas de fato cabe a Platảo), mas sobre a mãe da lógica. "Ela parece ter sido esquecida e desconhecida. Mas talvez a origem da lógica encontra-se nem no pai e nem na mãe, mas em ambos. O que é o Lógos como tal?" (GA 55, 239.) O senticio esquecido é o sentido mais originánio?

Para a lógica, o Lógos é asserçâo, enunciado e enquanto asserçâo o Lógos pertence ao dizer e o dizer é discurso (Rede) e linguagem (Sprache). O Lógos é uma manifestação da linguagem. Esta definição é aceita desde muito tempo na tradição ocidental Contudo, o Logos não stgnifica de saida palavra, discurso, linguagem. "Isto resulta do fato que o significado fundamental da palavra grega Lógos de nenhum modo pode ser 'discurso' ou 'linguagem' e que näo alude como tal ao lingüistico ou verbal. De outro lado, é sem dúvida certo que o termo Lógos e o verbo correspondente legein desde cedo significaram para os gregos tanto 'dizer' (sagen) como 'falar' (reden)" (GA 55, 239).

Este é o enigma ignorado durante dois milênios e meio: "Lógos e legein significam discurso, palavra e dizer, enquanto que o significado originário de Lógos e legein de modo nenhum está relacionado com o modo lingüistico $\theta \mathrm{com}$ a atividade lingüistica" (GA 55, 24).

$O$ encaminhamento deste tipo de questionamento 6 que permite uma aproximação adequada daquilo que permaneceu impensado no pensamento grego do Lógos. Assim, Heidegger situa o que seja lógica: "Meditação sobre o Lógos que é a manifestaçäo originária do ser mesmo, que se desvela como o que originariamente é para ser pensado" (GA 55, 278).

O caminho para tal investigação não se restringe a um trabalho lexicográfico $e$ historiográfico, mas sim buscar o essencial que se diz em poucas palavras, através de uma preparaçăo adequada que "consiste na experiência do ămbito essencial a partir do qual brota a palavra singular pronunciada" (GA 55, 241). Mas o investígador tem uma surpresa: a busca da significaçäo esquecida das palavras fundamentais subitamente revela que "a palavra e o que ela nomela age sobre nós e já tem agido sobre nós, antes mesmo que nos tenhamos posto a carminho para sua elucidaçẫo" (GA 55, 141). Igualmente, atrás da história das palavras, da etimologia, se esconde uma outra história que a historiografia näo consegue atingir e que o próprio pensar humano nâo consegue apanhar se năo the é dado. Mas mesmo recebendo tal dom, o homem pode enganar-se e enganar-se-á. 
Trata-se entāo de entrar num dominio obscuro. Sabemos que é pelo seu pensamento do Lógos que Heráclito mereceu o apelido de "o obscuro". Assim como existem três perigos no pensar, há trẻs tipos de obscuridade:

1. a obscuridade da confusâo conceitual;

2. a obscuridade do ocultamento;

3. a obscuridade da claridade que retém.

É nesta terceira obscuridade, própria de Heráclito, que se trata de encontrar o Lógos originário. A condição prévia é o que indica o fragmento 50: a escuta. Vejamos alguns resultados do trabalho de Heidegger com este fragmento e suas propostas de tradução interpretativa:

Fragmento 50: ouk emou allà tou Lógou akoúsantas homologein sophón estin Hèn Pánta. (Năo de mim, mas do Lógos tendo ouvido é sábio homologar tudo é um. $)^{6}$

Traduçōes de Heidegger:

a. Vós nāo tendes escutado apenas a mim, mas se tendes escutado (obedientes ao Lógos) o Lógos, então o saber (consiste em), dizer o mesmo com o Lógos dizendo: um é tudo.

(Habt ihr nicht bloss mich gehört, sondern habt ihr (dem Lógos gehorsam) auf den Lógos gehört, dann ist Wissen (das darin besteht), mit dem Lógos das Gleiche sagend zu sagen: Eins ist alles) (GA 55, 259).

b. Não me escuteis a mim, o mortal que vos fala; mas sede atentos ao pousar/colheita/leitura que recolhe; começai por pertencer-lhe, entáo ouvireis propriamente falar; um ouvir $\dot{\theta}$, enquanto tiver lugar um deixar-estendido-diante-umacoisa-junto-da-outra, diante do qual se estende o conjunto, o deixar-estendido que reúne, o pousar que recolhe. Quando acontece que o delxar-estendido-diante deixa estendido, produz-se, então, alguma coisa de bem-disposta; pois o bemdisposto propriamente dito, o destino, somente é: o único-uno que tudo unifica.

(Nicht mich, den sterblichen Sprecher, hört an; aber seid horchsam der lesenden Lege; gehort ihr erst dieser, dann hört ihr damit eigentlich; solches Hören ist, insofern ein beisammen-vor-liegen-Lassen geschieht, dem das Gesamt, das versammelnde liegen-Lassen, die lesende Lege vorliegt; wenn ein liegenLassen geschieht des vor-liegen-Lassens, ereignet sich Geschickliches; denn das eingentlich Geschickliche, das Geschick allein, ist: das Einzig-Eine einend Alles) (VA, 217-218).

c. Se vós nảo tivestes escutado apenas a mim, mas sim docilmente tívestes prestado atenção ao recolhimento/reuniăo oniginánio, entăo se dá (o) saber que consiste no colher-se no recolhimento/reuniào e no ser recolhido no 'um é tudo?.

(Flabt thr nicht bloss mich angehört, sondern habt ihr fügsam auf die ursprüngliche Versammiung geachtet, dann ist (das) Wissen, des darin besteht, auf die Versammlung sich zu sammeln und gesammelt zu sein in dem 'Eins ist Alles') (GA 55, 308).

B Para os fragmentos de Herácito, apresentamos inicialmente uma traduçầo corrente, em geral retirada de Os pré-soctáticos: fragmentos, doxografia e comentános. 2. ed. Säo Paulo: Abril Cultural, 1978. 
Três aspectos são sublinhados nesse fragmento:

1. O importante é de inicio o artigo definido, ho Logos; o pousar: o puro fato do deixar-estendido-diante-em-seu-conjunto aquilo que por si mesmo está estendido diante em seu estar-aí. Assim, o Logos se desdobra em seu ser como o puro ato do pousar que recolhe e colhe. O Loggos é o originário recolhimento da colheita primordial a partir do pousar primordial. O Lógos é: o pousar que recolhe, e mais nada.

2. A relaçắo com esse Logos se define pelo escutar (akouein), que presta atenção a uma voz não humana, uma voz silenciosa. A polissemia de escutar: Hören (ouvir), Horchen (escutar), Gehorchen (obedecer), horchsam (audiente), Gehorsam, etc. Este escutar/obedecer nāo é servilismo, mas abertura como liberdade. A partir daqui outra definiçẫo de homem seria possivel: o homem como a possibilidade de uma escuta obediente. A natureza deste escutar determina-se a partir do Lógos, que não pode ser qualquer coisa entre as coisas, assim como 0 escutar que the é conforme não pode ser ocasional, "Se os mortais querem realmente escutar, importa que fá tenham ouvido o Lógos com um ouvido que não significa nada menos que pertencer ao Lógos" (VA, 208). Pertencer ao Lógos e reconhecer esta pertença não se faz sem a escuta obediente, base essencial da resposta, que funda toda autêntica responsabilidade. Aqui vemos o enlace entre ser e estar em débito e a responsabilidade, ou seja, dá-se aos mortais a possibilidade de reconhecer o que devem ao Lógos originário, aquele recolhe a partir do pousar primordial e igualmente se abre a possibilidade, na escuta obediente, de responder, instaurando 0 âmbito da palavra e da linguagern.

3. A oposiçāo entre 'nåo a mim'/ 'mas o Lógos. Esta recusa inicial e fundamental remete para uma relação decisiva: o homologein no qual se realiza a verdadeira proximidade com o Lógos. Assim, a quarta lógica de Heidegger será uma lógica da homologia, não no sentldo religioso ou matemático ou de opiniões, mas homologia no sentido de Heráclito: "Toda igualdade (Gleichheit) e sobretudo a igualdade do homologein, funda-se numa diversidade. Somente o diverso pode ser igual" (GA 55, 250).

Dai resulta o axioma: "Quanto mais a mesmidade do mesmo é originária, mais essencial é a diferença em sua igualdade, mais interna/profunda é a igualdade do igual" (GA 55, 250).

Fica claro que o acordo/homologein nảo se dá, originariamente, no nível da intersubjetividade, mas o acordo (homologein/Einverständnis) é com o Logos sobre - Lógos (GA 55, 251). Quando o legein dos mortais se conforma com o Lógos, então acontece homologein. Este se recolhe no hèn/um, em seu imperar unificador. Tomando o fragmento 32 , Heidegger aponta para o lugar deste Hén, que nâo deve ser interpretado corno igual a Zeus, ao divino, pois isso implicaria um risco de apagamento da diferença ontológica.

Fragmento 32: Hèn tó Sophòn légesthai ouk ethélei kai ethêlei Zenòs ónoma ( $O$ um, o único sábio, não quer e todavia quer ser chamado pelo nome Zeus).

Tradução de Heidegger: "O unicamente uno que unifica, o pousar que recoIhe, nāo está preparado mas também está preparado para ser nomeado Zeus" (VA, 215). 
E isso porque o Hèn, não aceitando ser chamado Zeus e assim ser rebaixado ao nivel de ser uma coisa presente entre outras, ao mesmo tempo aceita o nome de Zeus: isto porque o todo das coisas presentes sob a direçâo da coisa suprema é o próprio Hèn enquanto Zeus. Entretanto, o Hèn é o único a ser o tó Sophòn, o bem-disposto, isto é, o destino mesmo: o recolhimento do destino no seio da presença.

\subsection{3 - Os très caminhos para o Lógos originário}

Situado o modo de aproximar-se do Lógos de Heráclito, Heidegger propöe três caminhos que podemos caracterizar como caminho 'ontológico', caminho 'semântico' e caminho 'psicológico'.

1. O caminho ontológico: O Lógos como Um e tudo: hén pantá einaí (f. 50) (GA 55, 261-266). Trata-se, neste fragmento, de uma unidade numérica (Einzahl), de identidade (Selbigkeit), de unificaçāo (einigende Einheit) ou de unariedade (Einzigkeit); e no tudo, de uma soma, de un conjunto, de uma totalidade, de um Todo ou de tudo isto ao mesmo tempo?

O ser comporta nele todas estas significaçōes. A ủltima palavra na série está na totalidade do fragmento, a primeira palavra, que decide a significação de todas as outras. Lógos é o próprio ser em sua força unificadora.

2. O caminho 'semântico' trata precisamente das múltiplas significações da palavra Lógos (GA 55, 266-270). A experiência fundamental que está em jogo ligase essencialmente ao que está presente no primeiro caminho: a experiência do legein, do colher e da colheita, do recolher, do pousar que recolhe. 0 importante nâo é fixcar-se na raiz etimológica da palavra lógos, mas alcançar a experiência a que nos remete e entäo, compreender a essêncla do Lógos a partir desta. No caso da colheita, parece que o primeiro é o respigar/recolher as espigas, e depois enceleirar/recolher no celeiro. Contudo, o que estrutura toda a atividade é reunir/recolhimento (Sammlung). Não se trata de fazer uma coleção, reunindo o que já está aí, mas de um 'recolhimento' originário, que precisa ser pensado em conjunto com physis e aletheia, quando então pode se abrir uma possibilidade originária de pensar em conjunto gesto e palavra, escritura e discurso, leitura e compreensâo (GA 55, 270).

3. O terceiro caminho, 'psicológico', centra-se no fragmento 45 , que recebe uma nova tradução de Heidegger (GA 55, 279-285). É necessánio pensar a psyche grega partindo da physis.

Este fragmento corresponde ao zoon logon echon de Aristóteles, antecipandose a este e recortando uma definição nāo metafisica do homern. Comumente, esse fragmento é lido metafisica e psicologicamente. Aqui se retorna à recusa do psicologismo, como já estava presente na primeira lógica de Heidegger.

O problema especifico da quarta lógica se encontra na interseçäo do que ensina o fragmento 50 em conjunto com o fragmento 45 , ou seja, pensar a regiâo sem objeto do Lógas originário. "A carência de objeto que caracteriza a regiäo é um sinal não de diminuição, mas sim superioridade do ser" (GA 55, 336). 
O destino da metafísica é de trazer à luz, através de sua história, a diferença entre o ser em relação ao ente, para que um dia ela se torne experiència. É então que o pensar sofre sua verdadeira mutaçâo (GA. 55, 338-339).

Fragmento 45: Psyches peirata ian ouk an exeurojo, paran epiporeuomenos, odon out $\omega$ bathun logon echei (Limites da alma não os encontrarias, todo caminho percorrendo; tăo profundo lógos ela tem).

Traduçôes de Heidegger:

a. Ainda que tu percorras todo caminho, não poderás mais encontrar em teu curso os confins extremos da alma; tão vasto pousar/colheita/leitura (recolhimento) ela tem.

(Der Seele äusserste Ausgänge auf deinem Gang nicht wohl kannst du sie ausfinden, auch wenn du jeden Weg abwanderst; so weitweisende Lese (Sammlung) hat sie) (GA 55, 282).

b. Ainda que tu percorras todo caminho, năo poderás mais encontrar em teu curso os confins extremos do distender recolhendo; tão vasto é indicado seu recolhimento.

(Des einholenden Ausholens äusserste Ausgange auf deinem Gang nicht wohl kannst du sie ausfinden, auch wenn du jeden Weg abwanderst; so weit gewiesen ist ihre Sammiung) (GA 55, 309).

Este fragmento levanta a questão: até onde vai a alma? Onde ela se detém? E o fragmento 50 responde: na escuta do Lógos. A conjunçâo de homologein e da psyche representa a saida näo psicológica de toda psicologia e ela define ao mesmo tempo a última compreensão heideggeriana da intencionalidade. A intencionalidade é aqui pensada em termos topológicos, como 'caminho' e 'encaminhamento'. Todas as determinaçōes ficaräo vazias de sentido se não houver una 'regiảo' originária na qual se pode fazer o caminho.

Esta região originánia é o Lógos, donde sua enigmática presença/ausẻncia formulada no fragmento 72: "Daquilo, com que mantêm continuo contato, do Logos discordam; e as coisas que encontram diariamente parecem-lhes estranhas." Igualmente, no fragmento 16 (Tó mè dynớn pote pôs án tis láthoi? Como pode alguém esconder-se diante daquilo que jamais tem ocaso?) (VA, 251-252), vemos que a relação do homem com o ser nāo é uma duplicação transcendental da relação do homem com os entes, mas a duplicidade destas duas relaçōes reúne o que náo se đeixa mais unificar, o que determina os confins năo alcançávels da psyché. Aqui se enraiza da cesura/fenda/rasgadura (Riss) e a clivagem/discórdia (Zwiespalt): o homem essencialmente dividido, não por uma clivagem do eu, mas pela diferença que atravessa seu ser. A clivagem (Zwiespait) deve ser pensada como 'duplicidade/prega' (Zwiefalt) apenas por causa do poder unificante do Lógos. O lugar desta duplicidade apenas pode ser procurado, sendo o Lógos a sua regiâo (Gegend). Disto decorre a recomendação precisa de Heidegger de que é preciso delimitar o mais possivel a essência do Lógos antes de toda consideração do lógos humano e pensar o Lógos como "relaçāo pura, não originada e somente isso" (GA 55, 328). 
Este Lógas originário é uma aporia; è ao mesmo tempo recolhimento originário e panta kechorismeneon (fragmento 108), traduzido comumente por 'separado de tudo', situando-se aqui o Lógos como um precursor do absoluto da metafisica.

Fragmento 108: okoswv logous ekousa, oudeis aphikneitai es touto, aste ginuskein oti sophon esti pantan kechorismenon (De quantos ouvia as liçöes nenhum chega a esse ponto de conhecer que a (coisa) sábia é separada de todas.)

Traduçāo de Heidegger:

Dos muitos logoi que eu (já) escutei, nenhum alcançou o ponto de onde lhe é familiar que o propriamente a ser sabido essencializa em relação a todo sendo a partir de sua (própria) região.

Sovieler logoi ich (schon) vernommen habe, keiner gelangt dorthin, von wo aus er vertraut ist damit, dass das eigentlich Zuwissende im Bezug auf alles Seiende aus seiner (eigenen) Gegend west (GA 55, 330).

Heidegger resgata, para alem da acepçäo habitual do verbo chorizein, a noçâo de chora, a hiância que deixa ser uma regiăo. Aqui se situa a raiz da topologia heideggeriana e o pensar da 'regiâo' (Gegend), e o Lógos como sendo "região sem objeto" (GA 55, 336). E, neste contexto, Heidegger diz: "Aqui domina a diferença originária entre ser e ente" (GA 55, 338).

A essência mais originária đo Lógos corresponde a essência mais originária da verdade, como é pensada por Parmênides. A topologia do ser supōe o desdobramento da esșência da própria verdade. O Lógas mais origináno torna possivel um poein kata physin. Mas todo surgimento/eclosäo é ao mesmo tempo retençẩo e reserva.

O pensamento grego nāo conseguiu nomear este segundo movimento e pensá-lo simultaneamente. A tentativa de Heidegger é surpreendente: a lógica de Heráclito recebe seu verdadeiro estatuto, na medida em que o filósofo conseguiu dizer "a coisa mesma" que permaneceu tanto tempo não đita e cujo dizer não se acabará jamais. Isso quer dizer que os gregos, mesmo Heráclito, habitavam na essência da linguagem, mas nunca alcançaram explicitar o próprio lugar em que habitavam, ou seja, näo chegaram a pensar a essência da linguagem. Este espanto frente ao ato de Heidegger somente é possivel a partir do pensar que ad-vém, ou seja, este ato de Heidegger supōe o próprio encaminhamento para sua possibilidade mais essencial: "A elucidação repousa na suposiçāo do Ereignis" (GA 55, 377).

\section{3- A palha e o ouro}

O fragmento 9 nos apresenta a oposiçăo entre a palha e o ouro: asnos apanham antes a palha que o ouro. Heidegger interpreta essa oposiçäo em termos da diferença ontológica, sendo o brihho inaparente da clarificação do ouro algo que năo se deixa apanhar, um brilho que brota do inviolado velar-se, retraindo-se sempre ali onde algo se mostra. Por isso, é possivel ver neste brilho, como puro acontecer-manifestando-se, o mais obscuro. "Heráclito charna-se ho Skoteinós. Também para o futuro manterá este nome. Ele é obscuro porque, questionando, pensa em direção da clanficação" (VA, 274). Escolher entre a palha e o ouro, como se fosse um solução radical, também pode ser um engano, pois os mortais não vivem sem a palha. Năo há como pular fora do mundo dos entes. Podemos lembrar uma 
anedota sobre Heráclito, relatada por Aristóteles (Das partes do animais A 5, 645 a 17), que recebe estrangeiros enquanto se aquecia junto ao forno. Diante da surpresa destes, vendo-o no cotidiano, onvida-os a entrar, dizendo: "Pois também aqui estāo presentes deuses." Aqü, neste lugar banal e comum, onde busca se aquecer junto ao forno, se mostra toda a indigência de sua vida. È nesta indigêncla, nas palhas, onde habitam tanto os deuses quanto os mortais, que se retrai e se mostra o brilho inviolável do Lógos originário. E nesta direção que deve ser interpretado o fragmento 119: Ethos anthropo daimon.

Tradução de Heidegger:

"A habitação (familiar) é para o homem o aberto para a presentificaçâo do Deus (o năo familiar) (GA 9, 356).

Se habitação e o habitar é o nome adequado para aquilo que Heráclito nomeia como Ethos, entäo a ética, que abarca o drama humano da culpa/divida e responsabilidade, somente pode encontrar seu fundamento mais próprio nåo no próprio homem, mas naquilo que o ultrapassa desde sempre e o endereça para alhures: a interrogação pela verdade do ser enquanto acontecimento/apropriação. E, neste caminho, cada um está sempre em preparaçã̃o, e devemos nos precaver, como nos alerta Heráclito, contra a Hybris (fragmento 43), a desmeciida de tudo querer saber e de tudo poder (GA 39,66), própria do sujeito modemo, ávido de domínio, mas que acaba apenas recolhendo a palha em vez de saudar e agradecer ao ouro que se lhe escapa das mãos.

Para finalizar, cabe refletir sobre a advertència que nos deixa Heidegger:

"Sem đúvida, a situação do pensar é algo muito particular. A pelavra dos pensadoreb nåo possui propriamente autoridade. A palavra dos pensadores não conhece autores no sentido de escritores. A palavra do pensar é pobre em imagens e sem encanto. A palavra do pensar repousa na desilusāo daquilo que diz. $\mathrm{E}$, contudo, o pensar transforma o mundo. Ble transforma o num enigma cada vez mais profundo e obecuro, enigma que, quanto mais obscuro é, tanto mais é a promessa de uma claridade mais alta. $O$ anigma já há muito tempo nos fol prometido na palavra 'ser'. E por isso que 'ser' permanece apenas a palavra provisória. Cuidemos para que nosso pensar nâo corra apenas cegamente atrás dela. Consideremos primeiro que 'ser' originariamente signiflica 'presença', e 'presença': pro-duzir-se e durar no desvelamento" "... significa 'presença', e 'presença': pro-duzir-se e durar no desvela. mento" (VA, 221).

Culpa/divida e responsabilidade, segundo Heidegger e sua leitura de Heráclito, näo podem ser adequadamente interpretadas no quadro da subjetividade moderna, que restringe o ser do homem ou à sua consciência solipsista ou ao nível das relaçöes intersubjetivas. Todo encaminhamento operado por Heidegger busca uma nova concepçâo do existente humano, tomando como ponto inicial o fenoิmeno originário constituido por uma falta năo de um algo, mas do próprio ser. Deste modo, a interpretação existencial do ser/estar em débito remete ao serfundamento de um nada. Isto significa que o ser do Dasein se constitui a partir de um nada fundante enquanto débito originário, possibilitador de todos os tipos de falta e débitos. Ora, esse modelo de análise hermenêutico-fenomenológica perpassa todo o caminho de investigação do pensador, determinando o seu diálogo com as formulaçōes cruciais da tradição ocidental. Contudo, o fenơmeno da dívida e da responsabilidade é trabalhado e explicitado no próprio percurso do pensador. Não 
podemos deixar de observar que a obra de Heidegger é o grande resultado do trabalho de sua divida $e$ de sua responsabilidade diante da escuta da origem originária e silenciosa. Se o ser dá-se historialmente, constituindo uma tradiçāo. Cada un que é constituído nessa tradição carrega um débito impagável com a mesma. Esse débito ou dívida, mesmo sendo impagável, não exclư que se possa realizar o trabalho em torno dessa divida. Mais ainda, recusar essa divida é ficar jogado no impessoal e nas objetivaçōes próprias da näo-responsabilidade. Deste modo, realizar a preparaçăo para essa origem originária, manter-se na disposiçăo fundamental, que é a abertura para o que advém do ser como nada originàrio, e o que nos permite habitar o mundo, reconhecendo a divida com a tradição que nos constitui e respondendo com aquilo que podemos enunciar, cada um do lugar aparentemente banal e comum em que está situado. Reconhecer e agradecer ê o próprio trabalho da divida, do ser/estar em débito, momento de receber o dom do ser. Ora, um dom somente se realiza no ato de ser recebido, e o poeta, no dizer poético, é aquele que mais apto se encontra para receber esse dom, realizar essa passagem através do dizer essencial do poema, instaurando ser. O pensador, tomado pela palavia do pensar, em sua indigência, não recua diante da desilusão tanto de seu dizer quanto da ausência e retraimento/velamento do próprio ser. Confrontado com essa falta originária, o pensador se situa em divida, não se deixa tomar nas armadilhas das culpabilizaçōes próprias das onto-teologias e responde à trađiç̨âo que o funda pela sua obra, como abertura para aquilo que é sempre o mais digno de questão, o que ad̀-vém como dom de alhures.

\section{Chave de abreviaturas das obras de M. Heidegger}

\footnotetext{
SZ - Sein und Zeit: 11. ed. Tubingen: M. Niemeyer, 1967.

US - Unterwegs zur Sprache. Pfullingen: Neske, 1959.

VA $\quad-$ Vortäge und Aufsătze. 4 ed. Ptullingen: Neske, 1994.

W - Lógica. Lecciones de M. Heidegger (semestre verana 1934) en el legado de Helene Weiss. Barcelona: Anthropos, 1991.

GA - Cesamtausgabe. Frankfurt am Main: V. Kostermann (seguido do número do volume e do nùmero da página)

GA 4 - Eriäuterungen zu Hölderlins Dichtung. Frankfurt am Main: V. Klostermann, 1976. Frankfurt am Main: V. Klostermann, 1981.

GA 9 - Wegmarken. Frankfurt am Main: V. Klostermann, 1976. Frankfurt am Main: V Klostermann, 1981.

GA 20 - Prolegomena zur Geschichte des Zeitbegrifls. Frankfurt am Main: V. Klostermann, 1979.

GA 21 - Logik. Die Frage nach det Wahrheit. Frankfurt am Main: V. Kostermann, 1976.

GA 22 - Dle Grundbegnffe der antiken Philosophie. Frankfurt am Main: V. Kostermann, 1993.

GA 24 - Die Grundprobleme der Phänomenologie. Frankfurt am Main: V. Klostermann, 1975.

GA 25 - Pbänomenologische Interpretation von Kants Krtlik der reinen Vernunft. Frankfurt am Main: V. Klostermarn, 1978.

GA 26 - Metaphysische Anfangsgründe der Logik im Ausgang von Leibniz. Frankfurt am Main: V. Kostermann, 1978.

GA 29/30 - Die Grundbegriffe der Metaphysik: Welt, Endilchkeit, Einsamkeit. Frankfurt an Main: V Klostermann, 1983.

GA 31 - Vom Wesen der menschlichen Freiheit. Einleitung in die Philosophie. Frankfurt am Main: V. Klostermann, 1982.

GA 39 - Holderlins Hymnen 'Germanien' und 'Der Rhein'. Frankfurt am Maln: V. Klostermann, 1980 .
} 
GA 45 - Grundfragen der Philosophie. Ausgewähite "Probleme 'der' Logik". Frankfurt am Main: V. Klostermann, 1984

GA 49 - Die Metephysik des deutschen Idealismus (Schelling). Frankfurt am Main: V. Kostermann, 1991.

GA 51 - Gudbegriffe, Frankfurt am Main; V. Kloetermarin, 1981.

GA 52 - Höderlins Hymne 'Andenken'. Frankfurt am Main: V. Kostermann, 1982.

GA 53 - Hoiderin Hymne 'Der Lster'. Frankfurn am Main: V. Kastermann, 1984.

GA 54 - Pamenides. Ftankfurt am Main: V. Kostermann, 1982.

GA 55 - Horakijt. Der Anfang des abendlandischen Denkens Iogik. Heraklits Lehre vom Lógos. Frankfurt am Main: V. Klostermann, 1979.

GA 65 - Beiträge zur Phllosophie (Vom Ereignis). Frankfurt am Main: V. Klostermann, 1889.

\section{Referências bibliográticas}

ALLEMANN, B. Holderlin et Heidegger. Paris: PUR, 1987.

BAST, Rainer A., DELFOSSE, Heinrich P. Handbuch zum Textstudium von Martin Heideggers 'Sein und 'Zeft'. Stuttgart-Bad Constatt: Frommann-Holzboog, 1980. v. L

COURTINE, Jean-François, Heidegger et la Phénoménologio. Paris: J. Vrin, 1990.

FLEIG, Mario. Problemática de uma articulaçâo: tempo e eternidade. Rstudos Leopoldienses, v. 26, n, 120, p. $107-118,1990$ a.

—. Esquematismo e temporalidade em Ser e Tempo. Porto Alegre: UFRoS, $1990 \mathrm{~b}$.

- Heidegger com Kant: da imaginaçäo transcendental à temporalidade onginária. Estudos Lecpoldenses, v. 27, n. 123, p. 85-100, jun./ago. 1991.

GRBISCH, J. Holderlin et le chemin vers le sacré. In: HAAR, Michel et al. Martin Heidegger. Paris: L'Heme, 1983, p. 543-567.

- La Parole heurese. Martin Heidegger entre les choses et les mots. Paris: Beauchesne, 1987.

HAAR, M. Le Chant de Ja terro. Heidegger et les assises de l'histaire de l'étre. Paris: I'Heme, 1985.

KEL KEL, Arion L. La Jégende de Fêtra. Lengage et poésie chez. Heidegget. Paris: J. Vrin, 1980.

KISIEL, Theodote. The Genesis of Heidegger's 'Being and time'. Los Angeles: University of Celifomie Press, 1993.

LOPARIC, Zeljko. A Fenomenologia do agir em Sein und Zeit. Manuscrito, Campinas, v, 5, n. 2, p. $149-$ $80,1982$.

MACDOWELI, J. A. A gênese da ontologia fundemental de Martin Heidegger. Säo Paulo: HerderBdusp, 1970.

NUNES, Benedito. Passegam para o poético. Filosofia e poesia em Heidegget. Såo Paulo: Atica, 1986.

POGGELER, Otto. El camino del pensar de Martin Heldegger. Madrid: Allanza, 1986.

STEIN, Ernildo. Compreensáo e finitude. Estrutura e movimento da interrogaçäo heideggeriana. Porto Alegre: UFRGS, 1967.

- A questão do método ne filosofla. Um estudo do modelo beideggeriano. 2. ed. Porto Alegre: Movimento, 1983.

— Seis estudes sobre 'Ser e tempo' (Martin Heidegger). Petrópolis: Vozes, 1988a.

Semináno sobre a verdade. Liçies proliminares sobre o parágrafo 44 de Sein und Zeit. Petrópolis: Vozes, 1993

ZARANDER, Marlene. Heidegger ot les paroles de l'origine. 2. ed. Paris: J. Vrin, 19904. 